\title{
MODERATION EFFECT OF MORAL OBLIGATION ON STUDENT'S INTENTION TOWARDS ACADEMIC DISHONEST BEHAVIOUR: THE CASE OF PUBLIC UNIVERSITIES IN GHANA
}

\author{
YAYRA DZAKADZIE \\ Department of Psychology and Education, University of Education, Winneba, Ghana \\ Email: dyayra2014@gmail.com
}

Received: 25 June 2021, Revised and Accepted: 3 August 2021

\begin{abstract}
The study examined the moderation effect of moral obligation on students' intention towards academic dishonest behaviour. A surveyinferential design was used to randomly sample the views of 1,200 undergraduate university students. A structured questionnaire was used to collect. Structural Equation Modelling (SEM) and Conditional Process Analysis (CPA) were used for the analyses. Moral obligation statistically significantly moderated the intention to engage in academic dishonesty. It was concluded that an intention to engage in academic dishonesty decrease as moral obligation increases in the individual students. It was recommended that university authorities should introduce moral education as a core course among undergraduate students. This would instill in them a higher moral obligation in order to curb the academic dishonesty menace.
\end{abstract}

Keywords: Intention, Moral obligation, Academic dishonesty.

(C) 2021 The Authors. Published by Innovare Academic Sciences Pvt Ltd. This is an open access article under the CC BY license (https://creativecommons.org/licenses/by/4.0/) DOI: https://dx.doi.org/10.22159/ijoe.2021v9i6.42814. Journal homepage: https://innovareacademics.in/journals/index.php/ijoe

\section{INTRODUCTION}

There seems to be the perception that there is an upsurge in the prevalence of academic dishonesty among the players in the education enterprise, particularly students, as to what constitutes academic dishonesty. Jones, Taylor, Irvin, and Faircloth (2011) state that academic dishonesty includes cheating and plagiarism, the theft of ideas and other forms of intellectual property whether they are published or not. They further report that at the Florida Institute of Technology, academic dishonesty includes cheating, fabrication, facilitating academic dishonesty and plagiarism. Academic dishonesty is multifaceted and is comprised of various forms of plagiarism, cheating in tests and examinations, unauthorised help, and evading the process of assessment (Arhin \& Jones, 2009; Faucher \& Caves, 2009; Nonis \& Swift, 2001; Teferra, 2001) Similarly, Finn and Frone (2004), in their study, saw academic dishonesty as the violation of enfranchised rules or standard requirements for completion of school home works and examination. Such violations included cheating in examination, plagiarising, free-riding and copying of assignments. Staats, Hupp, Wallace and Gresley (2009) look at academic dishonesty as a type of deviant behaviour that impacts harmfully on the development of character, hurts others and jeopardizes the academic integrity of the particular institution. Students who engage in such deviant behaviour place their individual benefit over that of others and put the institution's integrity at risk. Dichtl (2003) suggests that academic dishonesty emanates from peers (learning), and this unethical behaviour establishes a culture whereby those honest students feel at a disadvantage. Though people nauseate it, yet most people may have compromised it once or several times in their academic study lives. Without honesty, academic integrity is not possible. Moreover, central to the mission of higher academic institutions is to instill good moral values in its graduates (Kibler \& Kibler, 1993). Unfortunately, academic dishonesty threatens this mission by undermining the value of learning (Bertram, 2008). In this era of dramatic change, the problem of ignoring ethics or values to achieve short-term goals arises. Educational institutions of higher learning are affected by this problem, as well. It is already known that moral values begin to develop in the family and in the institutions in which formal education is provided (Arslantas \& Acar, 2008). Educational institutions have important duties and responsibilities to help form an honest society and to raise individuals with high ethical principles (Levy \& Rakovski, 2006). Yet, academic dishonesty is becoming more and more common at every stage of education (Broeckelman-Post, 2008). The problem originally worsened with the introduction of information technologies (e.g., the internet, sophisticated cell phones, and wireless) into the education field, which witnessed 'academic dishonesty' to grow more easily and begin to affect every stage of education (Wowra, 2007). Murdock and Anderman (2006) study suggested that morality should be included as a predictor of students' decisions to cheat. Because moral obligation had been shown to increase the predictive ability of the theory of planned behaviour (Ajzen, 1991) and because it was noted as an important predictor in both models, it is included as a variable in this study, but it is used as a moderator variable with the expectation that students who report higher levels of moral obligation not to cheat will be less likely to cheat than students who report lower levels of moral obligation not to engage in academic cheating. A moderator is a variable that modifies a causal effect (Wu \& Zumbo, 2007). In essence, a moderator modifies the strength or direction (i.e., positive or negative) of a causal relationship of a variable (Frasier, Tix, \& Baron, 2004). Educational institutions have important duties and responsibilities to help form an honest society and to raise individuals with ethical principles (Levy \& Rakovski, 2006). Yet, academic dishonesty is becoming more and more common at every stage of education (Broeckelman-Post, 2008). Passow, Mayhew, Finelli, Harding and Carpenter (2006) posit that academic dishonesty undermines the credibility of learning. It also puts one's integrity at stake. Intentions to cheat correlated strongly with academic dishonesty behaviour (Harding, Mayhew, Finelli, \& Carpenter, 2007). Studies have shown that intentions to engage in academic dishonesty are a significant predictor of academic dishonesty behaviour (Mayhew, Hubbard, Finelli, \& Harding, 2009). Keith-Spiegel and Whitley (2001) offer moral ramifications of student academic dishonesty. First, students who cheat on examinations and assignments are more likely to receive higher grades than students who do not cheat. Therefore, honest students are placed at a disadvantage when their scores are compared to the grade point averages and examination scores of dishonest students. Such scores or grades will not be valid and consequently, they cannot be reliable (i.e., dependable). Also when students see others cheating and when the institution does not act to punish the offenders, students are left to believe that such behaviour is acceptable. The students may begin to 
believe that hard work does not lead to academic success and that dishonesty is the best way to be successful in college. These unattended moral ramifications may influence students' intention to commit academic dishonest behaviour. The issue, therefore, needs to be addressed. However, it looks as if the issue is yet to attract sufficient attention from researchers in the field of education. Subsequently, this study was undertaken to examine the moderating effect of moral obligation on the intention of undergraduate students towards academic dishonest behaviour in public universities in Ghana.

\section{RESEARCH QUESTION}

What is the moderation effect of moral obligation on students' intention to commit academic dishonest behaviour in public universities in Ghana?

\section{METHODOLOGY}

A survey-inferential design was used in this study. One thousand and two hundred $(1,200)$ undergraduate students participated. A simple random sampling technique was used to select the participants for the study. A structured questionnaire was used to collect data. The first section of the questionnaire assessed the prevalence of academically dishonest behaviours with sixteen (16) items. The second section assessed intention to commit academic dishonest behaviour with five (5) items. The third section assessed the moral obligations of students towards academic dishonest behaviour with three (3) items. All the items were close-ended items and scored polytomously. The reliability index for this scale was 0.82 . The research question was answered using Structural Equation Modelling (SEM) and Conditional Process Analysis (CPA).

\section{RESULTS}

To find out the moderation effect of moral obligation on the relationship between intention and academic dishonesty and more specifically to ascertain whether moral obligation moderated the relationship between intention and academic dishonesty, the SEM analysis was employed. The results showed that exogenous variables (attitude, goal, cost, selfefficacy and subjective norms) had a significant indirect effect on academic dishonesty. The relationship between the mediation variable and the criterion variable also yielded a statistically significant result $(0.265)$.

Table 1 presents the result of the moderation effect of intention and academic dishonesty.

Table 1: Moderation effect of moral obligation on the link between intention and academic dishonesty

\begin{tabular}{|l|c|c|c|c|}
\hline \multicolumn{1}{|c|}{ Variable } & Coeffi. & t-value & p-value & LLCI* \\
\hline Constant & 9.3740 & 103.2884 & 0.0000 & 9.1960 \\
\hline Moral Obligation & -0.0747 & -2.0904 & 0.0368 & -0.1449 \\
\hline Intention & 0.2084 & 6.6766 & 0.0000 & 0.1472 \\
\hline Interaction & -0.0387 & -2.7857 & 0.0054 & -0.0114 \\
\hline
\end{tabular}

${ }^{*}$ Lower Limit Confidence Interval (LLCI) and Upper Limit Confidence Interval (ULCI)

Table 1 presents the interaction effect of moral obligation on the relationship between intention and academic dishonesty. It is obvious that moral obligation and intention are significant predictors of academic dishonesty with $[\mathrm{t}(3,1196$ $=2.0900, \mathrm{p}<0.0050]$ and $[\mathrm{t}(3,1196=6.6800, \mathrm{p}<0.0000)]$ respectively. The interaction effect $[\mathrm{t}(3,1196=2.7900, \mathrm{p}<$ 0.0050] of moral obligation on the link between intention and academic dishonesty is statistically significant. The interaction is less than 0.0500 alpha level so there was a significant moderation. Moral obligation is a significant moderator of intention to engage in academic dishonesty. Both the upper and the lower level confidence interval did not include zero, so there was a statistically significant moderation effect in the population.

To further examine the moderation effects of moral obligation on the link between intention and academic dishonesty, the conditional process analysis was used and the result was presented in table 2 .

Table 2: Conditional effect of intention on academic dishonesty at the value of the moderator (moral obligation)

\begin{tabular}{|l|l|l|c|}
\hline \multicolumn{1}{|c|}{ Model obligation } & Effect & t-value & p-value \\
\hline Low (-3.5290) & 0.3264 & 6.5268 & 0.0000 \\
\hline Moderate (.0000) & 0.2084 & 6.6766 & 0.0000 \\
\hline High $(3.0529)$ & 0.0904 & 1.6394 & 0.1014 \\
\hline
\end{tabular}

Table 2 shows that the conditioned effect of moral obligation ranges from -3.5290 to higher 3.0529; however, a lower level of moral obligation (-3.053) mean that intention had a significant effect on academic dishonesty. And with an average level (.000) of moral obligation, intention had a positive significant effect on academic dishonesty and finally, at a higher level of moral obligation (3.053), intention to engage in academic dishonesty was not significant. This implies that as one moves from a lower level of moral obligation, there is a highly statistically significant positive relationship between intention and academic dishonesty to a statistically not significant level with high moral obligation. This means that the relationship between intention and academic dishonesty moves from positive statistically significant to statistically no significant as moral obligation increases. This implies that if an individual has a higher moral obligation, his intention to engage in academic dishonesty reduces but with low moral obligation, intention to engage in academic dishonesty increases.

\section{DISCUSSION}

The statistically significant inverse effect was found between moral obligation and intentions to engage in academic dishonesty. This finding contradicted similar studies on academic dishonesty, which found a positive effect (Ajzen, 1991). The moral obligation in this study was a significant moderator for the intention to engage in academic dishonesty. More importantly, it either increased or decreased the intention to engage in academic dishonesty. This confirms the findings of Beck and Ajzen (1991) and Harding et al. (2007). Indeed, moral obligation is key in informing intention to engage in examination malpractices, plagiarism, falsification, or any form of academic dishonest behaviour because of the belief system (Ajzen \& Fishbein, 2005) and their ethics. The effect and the inverse relationship of moral obligation with intention whether to engage in academic dishonesty or not indicate that students with a weak sense of moral obligation to avoid 
cheating will be more likely to cheat in a given situation. Therefore, it is obvious that the model statistically significantly fits the data. Indeed, the model provided an explanation that the level of the moderating variable that one possesses (moral obligation) determines whether the individual will ultimately end up engaging in academic dishonesty or not.

\section{CONCLUSION}

The moderating variable, moral obligation, moderated immensely the relationship between intention and academic dishonesty. An intention to engage in academic dishonesty decreases as moral obligation increases in the individual students. Similarly, an intention to engage in academic dishonesty increases as moral obligation decreases among the students.

\section{Recommendation}

University authorities should increase the barriers towards academic dishonesty and by making it more difficult to cheat. An example of these barriers could be stricter monitoring of examinations by the university authorities, introduction of computer-based testing to eliminate many opportunities to cheat that are inherent in paper-and-pencil tests and enforcing the use of electronic plagiarism software. Furthermore, university authorities should institute honour codes or make a concerted effort to disseminate stories about students who resisted opportunities to engage in academic dishonesty, students who received awards for integrity and efforts of students who actively support a culture of academic integrity. Such stories should be viewed as most significant and may have the greatest effect when conveyed by students and student leaders during an orientation session for fresh students. Finally, university authorities should introduce moral education as a core course for undergraduate students. This will instill in them a higher moral obligation in order to curb the academic dishonesty menace.

\section{ACKNOWLEDGEMENT}

Nil.

\section{AUTHORS CONTRIBUTIONS}

The author did the study single-handedly.

\section{CONFLICT OF INTEREST}

The researcher declared no conflict of interest in the conduct of the study.

\section{FUNDING SOURCE}

There was no funding from agency.

\section{REFERENCES}

- Ajzen, I. (1991). The theory of planned behaviour. Organizational Behaviour and Human Decision Processes, 50(2), 179-211. doi:10.1016/0749-5978(91)90020-T

- $\quad$ Ajzen, I., \& Fishbein, M. (2005). The influence of attitudes on behaviour. In D. Albarracin, B. T. Johnson and M.P. Zanna (Eds.), Handbook of Attitudes and principle change: Basic principles (173-221). NJ: Lawrence Erlbaum Associates.

- Arhin, A. O., \& Jones, K. A. (2009). A multidiscipline exploration of college students' perceptions of academic dishonesty: Are nursing students different from other college students? Nurse Education Today, 29, 710-714. doi:10.1016/j.nedt.2009.03.001

- Arslantas C. C., \& Acar, G. (2008). Perceptions of academic and business dishonesty among senior level students. Management, 19(60), 32-49. Retrieved from https://app.trdizin.gov.tr/publication/paper/detail/Tnpj eE1qazU
- $\quad$ Beck, L., \& Ajzen, I. (1991). Predicting dishonest actions using the theory of planned behaviour. Journal of Research in Personality, 25(3), 285-301. doi:1016/00926566(91)90021-H

- Bertram, G. T. (2008). Academic integrity in the twentyfirst century: A teaching and learning imperative. $A S H E$ Higher Education Report, 33(5), 123. Retrieved from https://eric.ed.gov/?id=EJ791635

- Broeckelman-Post, M. A. (2008). Faculty and student classroom influences on academic dishonesty. IEEE Transactions on Education. 51(2) 206-211. doi: 10.1109/TE.2007.910428

- Dichtl, J. (2003). Teaching integrity. History Teacher, 36(3), 367-373. Retrieved from https://eric.ed.gov/?id=EJ824488

- Faucher, D., \& Caves, S. (2009). Academic dishonesty: Innovating cheating techniques and the detection and prevention of them. Teaching and Learning in Nursing, 4(2), 37-41. doi:10.1016/j.teln.2008.09.003

- $\quad$ Finn, K. V., \& Frone, M. R. (2004). Academic performance and cheating: Moderating role of school identification and self-efficacy. The Journal of Educational Research, 97(3), 115-121. doi:10.3200/JOER.97.3.115-121

- $\quad$ Frasier, P. A., Tix, A. P., \& Barron, K. E. (2004). Testing moderator and mediator effects in counselling psychology research. Journal of Counselling Psychology, 51(1), 115134. doi:10.1037/0022-0167.51.1.115

- $\quad$ Harding, T., Mayhew, M., Finelli, C., \& Carpenter, D. (2007). The theory of planned behaviour as a model of academic dishonesty in humanities and engineering undergraduates. Ethics \& Behaviour, 17(3), 255-279. doi:10.1080/10508420701519239

- Jones, L., Taylor, R., Irvin, S., \& Faircloth, L. (2011) Academic integrity \& academic dishonesty: A handbook about cheating \& plagiarism. Retrieved from https://repository.lib.fit.edu/bitstream/handle/11141/26 01/JonesAcademicIntegrity.pdf?sequence=1\&isAllowed $=y$

- $\quad$ Keith-Spiegel, P., \& Whitley, B. (2001). Introduction to the special issue. Ethics \& Behaviour, 11(3), 217-218. doi:10.1207/S15327019EB1103_1

- $\quad$ Kibler, W. L., \& Kibler, P. V. (1993). When students resort to cheating. The Chronicle of Higher Education. Retrieved from https://www.chronicle.com/article/when-studentsresort-to-cheating/

- Levy, E. S., \& Rakovski, C. C. (2006). Academic dishonesty: A zero-tolerance professor and student registration choices. Research in Higher Education, 47(6), 735-754. Retrieved from https://www.jstor.org/stable/40197574

- $\quad$ Mayhew, M. J., Hubbard, S. M., Finelli, C. J., \& Harding, T. S. (2009). Using structural equation modelling to validate the theory of planned behaviour as a model for predicting student cheating. The Review of Higher Education, 32(4), 441- 468. doi:10.1353/rhe.0.0080

- Murdock, T. B., \& Anderman, E. M. (2006). Motivational perspectives on student cheating: Toward an integrated model of academic dishonesty. Educational Psychologist 41(3), 129-145. doi:10.1207/s15326985ep4103_1

- Nonis, S., \& Swift, C. W. (2001). An examination of the relationship between academic dishonesty and workplace dishonesty: A multi campus investigation. Journal of Education for Business, 77(2), 69-77. doi:10.1080/08832320109599052

- $\quad$ Passow, H. J., Mayhew, M. J., Finelli, C. J., Harding, T. S., \& Carpenter, D. D. (2006). Factors influencing engineering students' decisions to cheat by type of assessment. Research in Higher Education, 47(6), 643-684. doi:10.1007/s11162-006-9010-y

- $\quad$ Staats, S., Hupp, J. M., Wallace, H., \& Gresley, J. (2009). Heroes don't cheat: An examination of academic dishonesty and students' views on why professors don't report cheating. Ethics and Behaviour, 19(3), 171-183. doi:10.1080/10508420802623716

- Teferra, D. (2001). Academic dishonesty in African universities-trends, challenges, and repercussions: An 
Ethiopian case study. International Journal of Educational Development, 21(2), 163-178. doi:10.1016/S07380593(00)00037-7

- Wowra, S. A. (2007). Academic dishonesty. Ethics \& Behaviour, 17(3),

doi:10.1080/10508420701519122
- Wu, A. D., \& Zumbo, B. D. (2007). Understanding and using mediators and moderators. Social Indicators Research: An International Interdisciplinary Journal for Quality of Life Measurement, 87(1), 367-392. doi:10.1007/s11205-007-9143-1 